\title{
Guru di Era Digital: Pelatihan Implementasi Schoology sebagai Learning Management System bagi Guru SMP Veteran Kota Cirebon
}

\author{
Surya Amami Pramuditya ${ }^{1}$, Cita Dwi Rosita ${ }^{2}$, Siska Firmasari², Sri Asnawati ${ }^{2}$ \\ 1, 2 Universitas Swadaya Gunung Jati, Indonesia
}

\begin{tabular}{|c|c|c|}
\hline \multicolumn{3}{|c|}{ A B S T R A C T } \\
\hline $\begin{array}{l}\text { TEACHERS } \\
\text { SCHOOLOC } \\
\text { VETERAN } \\
\text { two-way cor } \\
\text { is a distane } \\
\text { requires a le } \\
\text { platforms is } \\
\text { other and st } \\
\text { their profess } \\
\text { resource per } \\
\text { menus and } t \\
\text { them in le } \\
\text { implementa } \\
\text { subjects in } \\
\text { with evaluat } \\
\text { of the comn } \\
\text { enthusiastic, } \\
\text { actively par } \\
\text { on observati } \\
\text { in classroom }\end{array}$ & $\begin{array}{l}\text { IN THE DIGITAL ERA: TRAINING ON } \\
\text { Y AS A LEARNING MANAGEMENT SYS } \\
\text { IREBON CITY. Distance education is a natu } \\
\text { Imunication through the media between ed } \\
\text { that separates them. To integrate the th } \\
\text { rning management system (Learning Mana } \\
\text { schoology. Schoology allows users to create, } \\
\text { are academic content. Schoology provides s } \\
\text { onalism in the digital age, especially in the us } \\
\text { on trains participants with the lecture metho } \\
\text { ols contained in LMS Schoology, as well as } \\
\text { rning. The training stage consists of th } \\
\text { on phase of the training. The target of th } \\
\text { irebon Veterans Junior High School. Indica } \\
\text { on during the training process and post-trai } \\
\text { unity service activities, during the face-to- } \\
\text { only when the exercises were online (nor } \\
\text { cipated out of a total of } 9 \text { teachers who bec } \\
\text { ns, few teachers took part in online activities } \\
\text { teaching, which had to pursue productive w }\end{array}$ & $\begin{array}{l}\text { LEMENTATION OF } \\
\text { TEACHERS OF SMP } \\
\text { system that involves } \\
\text { students when there } \\
\text { mmunication process } \\
\text { tem). One of the LMS } \\
\text { ind interact with each } \\
\text { r teachers to improve } \\
\text { logy for learning. The } \\
\text { xplains how to use the } \\
\text { of how to implement } \\
\text { tion phase and the } \\
\text { is the teachers of all } \\
\text { ining implementation } \\
\text { tion. From the results } \\
\text {, the teachers looked } \\
\text { ce), only one teacher } \\
\text { th participants. Based } \\
\text { their busy operations } \\
\text { rning. }\end{array}$ \\
\hline Keywords: & Learning Management System, Schoology. & \\
\hline $\begin{array}{l}\text { Received: } \\
09.03 .2020 \\
\end{array}$ & $\begin{array}{l}\text { Revised: } \\
29.06 .2020 \\
\end{array}$ & $\begin{array}{l}\text { Available online: } \\
30.11 .2020\end{array}$ \\
\hline
\end{tabular}

\section{Suggested citation:}

Pramuditya, S., Rosita, C., Firmasari, S., \& Asnawati, S. (2020). Guru di era digital: Pelatihan implementasi schoology sebagai learning management system bagi guru SMP Veteran Kota
Cirebon
Jurnal Pengabdian
Pada
Masyarakat,
$5(4)$,
1043-1050.

https://doi.org/10.30653/002.202054.457

Open Access I URL: http://ppm.ejournal.id/index.php/pengabdian/article/view/457

\footnotetext{
${ }^{1}$ Corresponding Author: Program Studi Pendidikan Matematika, FKIP Universitas Swadaya Gunung Jati; Jl Perjuangan No. 01, Kota Cirebon, Indonesia. Email: amamisurya@gmail.com
} 


\section{PENDAHULUAN}

Pengabdian kepada masyarakat merupakan salah satu program rutin yang dilakukan oleh dosen-dosen di lingkungan Universitas Swadaya Gunung Jati (UGJ) Cirebon yang diwadahi langsung oleh Lembaga Pengabdian Masyrakat (LPM). Berbagai kegiatan pengabdian dilakukan sesuai dengan bidang ilmu yang dimiliki, salah satunya di bidang pendidikan. Kegiatan ini dilatarbelakangi pula oleh kebutuhan masyarakat akan berbagai informasi dan pengetahuan di era digital, terutama yang berhubungan dengan pembelajaran. Profesionalitas guru dalam pengajaran dan pendidikan menuntut mereka untuk selalu mengikuti perkembangan zaman. Kecanggihan teknologi memberikan ruang gerak yang luas bagi guru dan siswa untuk memanfaatkan berbagai platform dan aplikasi yang tersedia di dunia maya.

Hasil wawancara dengan para guru SMP Veteran Kota Cirebon, diperoleh informasi bahwa mereka memiliki ketertarikan dengan perkembangan pembelajaran di era digital. Pembelajaran yang dimaksud adalah yang sedang berkembang pesat saat ini yaitu pembelajaran terbuka jarak jauh. Pembelajaran ini dapat diakses baik oleh siswa maupun guru dan orang tua dimanapun kapanpun. Terjadilah pergeseran pola pembelajaran dari tatap muka yang konvensional ke arah yang lebih terbuka dan fleksibel (Zamaludin dkk, 2016). Akses tidak terbatas dengan memanfaatkan fasilitas yang dimiliki sekolah berupa laboratorium komputer yang lengkap di sekolah tersebut, maupun fasilitas pribadi berupa ponsel dan laptop.

Pengertian pendidikan jarak jauh (distance education) dinyatakan oleh berbagai kalangan dari berbagai sudut pandang dengan cara yang beragam. Berbagai peristilahan telah menyemarakkan dan menambah dinamika sistem pendidikan jarak jauh, seperti pendidikan korespondensi (correspondence education), sekolah korespondensi (corespondence schools), pendidikan terbuka (open education), belajar terbuka (open learning), belajar melalui udara (education of the air), belajar elektronik ( $e$ learning), pendidikan elektronik (e-education), belajar maya (virtual learning), dan lain lain (Siahaan, 2005). Apa pun istilah yang dipergunakan, pada dasarnya pendidikan jarak jauh merupakan suatu proses pendidikan tanpa pembatas dinding sekolah (education without walls).

Pendidikan jarak jauh ditawarkan lintas ruang dan waktu sehingga siswa memperoleh fleksibilitas belajar dalam waktu dan tempat yang berbeda, serta menggunakan beragam sumber belajar (Irwansyah, 2018). Pendidikan jarak jauh merupakan suatu sistem pembelajaran alamiah yang melibatkan komunikasi dua arah melalui media antara guru dan siswa, bilamana terdapat suatu jarak yang memisahkan mereka. Komunikasi dua arah ini sekali-sekali dapat dilakukan secara tatap muka disamping pada umumnya dilakukan maupun melalui media komunikasi, dan bertujuan membantu siswa dalam proses pembelajaran. Untuk mengintegrasikan proses komunikasi tersebut dibutuhkanlah suatu sistem manajemen pembelajaran (Learning Management System). LMS merupakan sebuah sistem pembelajaran inovasi yang mencakup dalam bidang teknologi informasi dengan memanfaatkan aplikasi open source yang dapat diunduh secara gratis di internet (Sanova, 2018).

Salah satu platform LMS adalah Schoology. Schoology adalah suatu aplikasi yang menggabungkan antara LMS dengan jejaring sosial (Haryanto, 2018). Schoology memiliki keunikan dibandingkan dengan LMS lain, yaitu memiliki tampilan yang 
mudah digunakan seperti facebook (Dewantara dkk, 2018). Schoology juga memiliki fitur yang sangat lengkap dengan berbagai alat pembelajaran sama seperti dikelas seperti absensi, tes dan kuis, dan kotak untuk mengumpulkan tugas atau pekerjaan rumah (Ulva dkk, 2017). Melalui Schoology diharapkan pula siswa dapat mengunduh materi pelajaran, slide presentasi, video tutorial, game, dan diskusi yang diberikan oleh pengajar (Murni, 2016). Siswa dapat memanfaatkan kesempatan belajar di luar kelas, menggunakan smartphone pribadi yang mereka miliki atau mengunjungi laboratorium komputer sekolah, karena keerbatasan waktu belajar efektif di kelas.

Berdasarkan penjelasan di atas, maka perlu dilakukan adanya kegiatan pelatihan untuk memperkenalkan lebih dalam mengenai berbagai main menu dan tools yang terdapat dalam Schoology sebagai pilihan guru untuk menerapkan pembelajaran jarak jauh. Program kegiatan pengabdian yang dilakukan berupa pelatihan implementasi Schoology dalam pembelajaran sebagai Learning Management System. Pelatihan bertujuan agar guru dapat mengimplementasikan Schoology sebagai wadah pembelajaran jarak jauh. Diharapkan hasil kegiatan ini dapat menjadi salah satu referensi metode pembelajaran bagi guru SMP Veteran di era digital, dengan terus mengembangkan kemampuan dan profesionalitas dalam mengemban amanah pendidikan.

\section{METODE}

Kegiatan pengabdian yang dilakukan menggunakan metode pelatihan. Pelatihan merupakan pendidikan jangka pendek untuk mengajarkan tentang ilmu pengetahuan, keahlian, dan keterampilan yang diperlukan untuk melaksanakan tugas dan kewajiban seseorang sesuai bidang keahliannya (Elfrianto, 2016). Pelatihan dilakukan sehingga seseorang dapat memberikan kontribusi terhadap instansi melalui kemampuan dan keterampilan yang telah didapatnya, kemudian diaplikasikan dalam pekerjaannya untuk meningkatkan kualitas kerja. Pelatihan diperlukan karena keterampilan dan pengalaman baru diperlukan, disebabkan adanya tuntutan ataupun posisi yang baru (Hasan, 2018). Pelatihan dalam kegiatan ini bermakna bagi guru, dimana guru dapat kontinu mengkonstruksi setiap pengetahuan baru yang diperoleh untuk keperluan

Langkah-langkah dalam kegiatan pengabdian ini adalah sebagai berikut.

\section{Tahap Persiapan Kegiatan}

Tahap persiapan yang dilakukan meliputi :

1) Survei kebutuhan pembelajaran jarak jauh guru-guru SMP Veteran Cirebon.

2) Pemantapan dan penentuan lingkungan pembelajaran.

3) Penyusunan bahan/materi pelatihan, yang meliputi: makalah dan modul Schoology untuk kegiatan pelatihan bagi guru.

\section{Tahap Pelaksanaan Kegiatan}

Dalam tahap ini yang dilakukan pada pertemuan awal yaitu presentasi mengenai pengenalan Schoology, cara menginstal aplikasi Schoology baik di PC atau laptop maupun ponsel pribadi, pembuatan akun untuk guru dan siswa serta bagaimana tampilan keduanya, main menu dan tools yang terdapat di dalamnya serta cara pemanfaatannya. Presentasi ini dilakukan untuk memberikan pengetahuan dasar 
sebagai syarat implementasi lebih jauh dalam pembelajaran di SMP Veteran Kota Cirebon.

Pihak yang terlibat dalam kegiatan pelatihan ini adalah guru-guru dari berbagai bidang studi yang mengampu di SMP Veteran Kota Cirebon. Dosen sebagai pemateri utama membahas mengenai implementasi Schoology dalam pembelajaran di sekolah. Mahasiswa bertugas sebagai pendamping peserta jika mereka mengalami kesulitan pada saat mulai mengimplementasikan Schoology. Para mahasiswa yang bertugas tersebut merupakan mahasiswa-0mahasiswa yang terlatih dalam menggunakan Schoology. Hal ini dikarenakan mereka telah terbiasa menggunakan Schoology dalam perkuliahan, sehingga mereka tidak asing dalam pemanfaatan aplikasi tersebut. Kegiatan pelatihan bertempat di Laboratorium Komputer SMP Veteran Kota Cirebon.

Pelatihan dilaksanakan selama 2 minggu secara kontinu seiap harinya, yaitu tanggal 10-21 Februari 2020. Berikut jadwal pertemuan pada pelatihan implementasi Schoology dalam pembelajaran di sekolah,

1) Pada pertemuan pertama, yaitu tanggal 10 Februari 2020 pukul 13.00-16.00 WIB, pemateri memberikan penjelasan tentang pentingnya LMS dan pembelajaran jarak jauh serta cara kerja dan tampilan Schoology.

2) Pertemuan kedua s.d keempat, sesi pelatihan yang menitikberatkan pada implementasi pembelajaran jarak jauh menggunakan google drive, chat dan video. Pertemuan kedua s.d keempat dilakukan secara daring, dimana guru dan pemateri serta pendamping tidak berada dalam lokasi yang sama. Waktu yang diberikan dibatasi untuk setiap pertemuannya pada tanggal 11-20 Februari 2020, yaitu pukul 09.00-17.00 WIB. Guru tidak harus daring setiap saat, namun mereka diminta memantau dan berpartisipasi untuk setiap diskusi yang dikeluarkan oleh pemateri. Evaluasi dilaksanakan pada setiap pertemuan untuk mengurangi berbagai kendala yang ditemui di lapangan.

3) Pertemua kelima, verifikasi pertemuan-pertemuan sebelumnya. Dilakukan pada tanggal 21 Februari 2020 pada pukul 13.00-16.00 WIB. Pada sesi ini juga dilakukan evaluasi akhir pasca pelatihan dilaksanakan. Sesi terakhir dilakukan secara tatap muka.

Luaran yang diperoleh dari kegiatan pelatihan ini yaitu kemampuan guru dalam mengimplementasikan Schoology sebagai wadah pembelajaran jarak jauh. Diharapkan Schoology bisa menjadi salah satu media untuk mempermudah pembelajaran di era digital, dimana pembelajaran tidak lagi terpatok di ruang kelas saja, dengan model diskusi dan ujian yang based on paper, tetapi sudah mengenal pemanfaatan internet untuk belajar. Tidak hanya dimanfaatkan oleh guru tapi juga siswa milenial.

\section{HASIL DAN PEMBAHASAN}

Kegiatan pelatihan dilakukan oleh tim dosen dan mahasiswa yang dihadiri oleh guru-guru di SMP Veteran Kota Cirebon. Guru-guru yang hadir tidak dibatasi bidang ilmu, karena materi yang disampaikanpun sifatnya luas dan dapat digunakan untuk berbagai materi pelajaran di sekolah. Kegiatan awal yaitu tatap muka dilakukan pada tanggal 10 Februari 2020 di Laboratorium Komputer dimulai pukul 13.00-15.30 WIB, dalam suasana kekeluargaan dan penuh antusias dari peserta pelatihan. Kegiatan 
bertemakan "Pelatihan Implementasi Schoology sebagai Learning Management System bagi Guru SMP Veteran Kota Cirebon" diawali dengan diskusi singkat mengenai pengenalan Learning Management System, dilanjut aplikasi Schoology.

Peserta pelatihan menanggapi antusias dan secara keseluruhan menyatakan bahwa mereka pernah mendengar mengenai Learning Management System dan aplikasi Schoology, namun belum mengetahui secara jelas mengenai apa itu Learning Management System dan Schoology, bagaimana cara memanfaatkannya, dan apa saja aplikasi yang dapat digunakan untuk membantu penyusunannya. Kemajuan teknologi menyongsong abad 21 saat ini, para guru memperoleh tuntutan baru yakni memahami dan memanfaatkan berbagai produk digital terkait dunia pendidikan. Teknologi saat ini sudah masuk ke berbagai pelosok negeri, sehingga setiap guru khususnya dan tenaga kependidikan umumnya tidak lagi beralasan untuk tidak belajar memanfaatkan fasilitas ini.

Setelah memperoleh kesimpulan awal, kemudian pelatihan Implementasi Learning Management System menggunakan Schoology siap untuk dipresentasikan oleh narasumber. Penyampaian materi diawali dengan pengertian Learning Management System dan aplikasi Schoology. Materi dilanjut dengan menu apa saja yang terdapat aplikasi Schoology dan kegunaannya. Peserta tampak antusias dengan penyampaian materi terlihat dengan fokusnya mereka memperhatikan apa saja yang disampaikan oleh narasumber. Untuk mempermudah peserta pelatihan memahami materi yang disampaikan, selanjutnya narasumber meminta peserta untuk menyertai dengan implementasi langsung. Karena sebagian besar guru membawa laptop pribadi, maka instalasi dari aplikasi Schoology dapat dilakukan langsung pada komputer masingmasing. Berikut adalah tampilan dari kegiatan awal yang terlihat pada Gambar 1 dan Gambar 2.

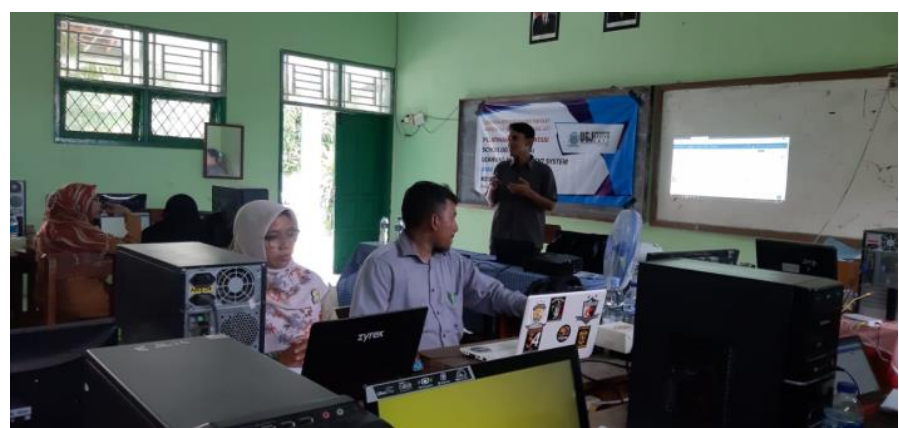

Gambar 1. Presentasi Singkat Mengenai Pengenalan LMS dan Aplikasi Schoology

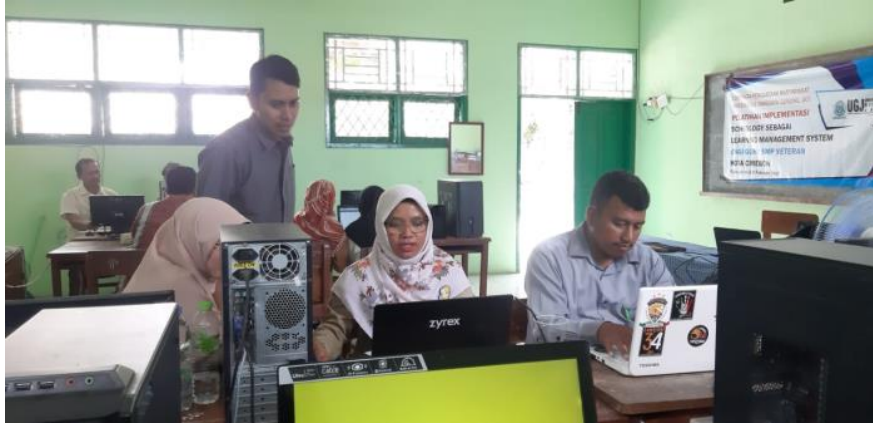

Gambar 2. Instalasi Aplikasi Schoology dan Pengenalan Berbagai Tools 
Sesi terakhir dari kegiatan pelatihan ini adalah sesi tanya jawab. Pertanyaan yang disampaikan oleh peserta lebih fokus pada bagaimana cara memanfaatkan berbagai menu dan tools dalam aplikasi Schoology sehingga dapat memaksimalkan penggunaannya. Keseluruhan pertanyaan tersebut dijawab oleh narasumber dengan pemaparan melalui pemanfaatan semua menu yang tersedia dengan berbagai pengembangan yang dapat dilakukan oleh guru, serta disampaikan pula bahwa selain melalui pernagkat PC dan laptop yang dimiliki baik oleh siswa dan guru, Schoology dapat pula digunakan melalui ponsel pribadi.

Pertemuan kedua sampai keempat dilaksanakan secara online antara narasumber dan guru-guru sebagai peserta pelatihan. Mereka mulai diarahkan untuk menggunakan Schoology sebagai wadah kegiatan online. Peserta pelatihan memposisikan diri sebagai siswa, dan narasumber sebagai guru. Sehingga peserta dapat mengteahui bagaimana jika mereka berada di posisi siswa, bagaimana tampilannya, dan menu apa saja yang aktif. Kelas virtual dibentuk untuk menjadi wadah diskusi. Berikut tampilan dari kegiatan online yang dilakukan narasumber dan peserta pelatihan pada Gambar 3.

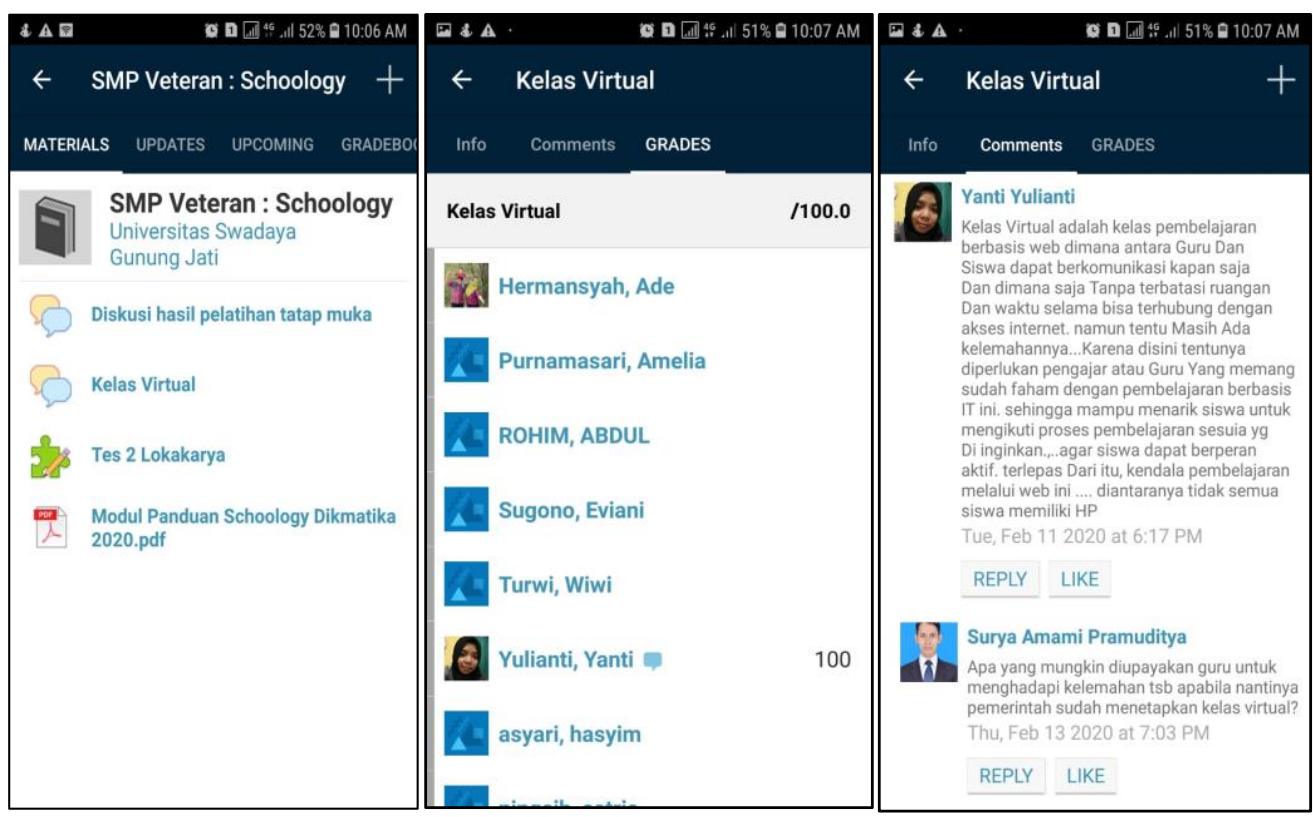

Gambar 3. Kelas Virtual dan Diskusi Online

Suasana pembelajaran yang menjenuhkan di ruang kelas dapat digantikan melalui media online dengan berbagai fitur yang berbeda dan lebih menarik minat belajar siswa. Berdasarkan observasi awal pada kegiatan tatap muka, terlihat bahwa guru-guru di SMP Veteran Kota Cirebon antusias dan termotivasi dalam mengikuti kegiatan pelatihan. Pembelajaran yang selama ini mereka gunakan masih bersifat konvensional dan terikat dengan ruang kelas saja. Fenomena era digital yang menuntut guru lebih profesional dengan memanfaatkan kecanggihan teknologi, menjadi salah satu alasan pelatihan ini menjadi sangat bermanfaat bagi mereka. Selama ini guru-guru memanfaatkan teknologi sebatas penggunaan aplikasi Microsoft Word dan Power Point untuk pelaporan dan presentasi materi pelajaran. Informasi terkait Learning Management 
System sudah pernah mereka ketahui hanya tidak mendalam dan belum sampai pada pemanfaatan menu yang ada.

Pelatihan Learning Management System menggunakan Schoology yang telah dilaksanakan walaupun secara respon terlihat sangat menarik minat guru-guru mata pelajaran sebagai peserta, namun terdapat beberapa kegamangan bagi mereka. Kegamangan tersebut adalah ketika Learning Management System telah mereka gunakan, pembelajaran akan menjadi kurang efektif. Dikarenakan kondisi siswa pada saat memanfaatkan ponsel bukan untuk media belajar tapi membuka aplikasi lain yang tidak ada kaitannya, serta kekhawatiran guru bahwa materi ajar tidak tersampaikan secara sempurna. Kegamangan mereka dijawab oleh tim pelatihan dari UGJ, dengan cara adanya sesi pelatihan pemanfaatan Schoology secara online, sehingga guru dapat mengatur waktu kuantitas penyampaian materi, serta bagaimana memantau kualitas pembelajaran siswa. Hal ini dapat menjadi tambahan pengetahuan bagi guru-guru sehingga proses kegiatan belajar mengajar menggunakan Schoology dapat terlaksana dengan baik.

Pada pertemuan kelima atau pertemuan terakhir, diperoleh berbagai verifikasi dan evaluasi dari kegiatan selama lima pertemuan. Kegiatan tatap muka dapat diketahui keberhasilannya melalui antusias peserta pelatihan pada saat kegiatan berlangsung. Hanya saja sangat disayangkan pada saat kegiatan sesi online, tidak semua peserta kembali menunjukkan antusiasme mereka. Hal ini terlihat dari keaktifan yang ditunjukkan oleh 1 orang peserta saja dari 9 yang terdata di awal tatap muka. Setelah dilakukan observasi akhir, diketahui bahwa para guru beralasan kesibukan penyampaian materi di kelas yang menyebabkan mereka tidak memanfaatkan sesi online dengan baik. Kepasifan peserta berlangsung sampai waktu pelatihan online selama kurang lebih 2 Minggu berjalan.

\section{SIMPULAN}

Kegiatan pengabdian masyarakat di SMP Veteran Kota Cirebon berupa pelatihan implementasi Schoology dalam pembelajaran sebagai Learning Management System dapat memberikan pengalaman mengajar dengan menggunakan media baru bagi guru dalam menyelenggarakan pendidikan jarak jauh. Selain itu dapat menjadi pilihan komunikasi bagi guru dan siswa yang dilaksanakan di luar kelas.

\section{Ucapan Terima Kasih}

Terimakasih kepada pihak Lembaga Pengabdian kepada Masyarakat Universitas Swadaya Gunung Jati (LPM UGJ) atas hibah pengabdian yang telah diberikan, serta seluruh civitas SMP Veteran Kota Cirebon yang telah bersedia menjadi lokasi pengabdian.

\section{REFERENSI}

Elfrianto. (2016). Manajemen Pelatihan Sumber Daya Manusia dalam Meningkatkan Mutu Lulusan. Jurnal EduTech, 2(2), 46-58. 
Haryanto, S. (2018). Kelebihan dan kekurangan e-learning berbasis schoology (Studi PTK dalam pembelajaran mata kuliah academic listening). Prosiding Seminar Nasional Geotik 2018 (pp. 106-110).

Hasan, N, A. (2018). Pendidikan dan pelatihan sebagai upaya peningkatan kinerja pustakawan. Jurnal LIBRIA, 10(1), 95-115.

Irwansyah. (2018). Penyelenggaraan sistem pendidikan tinggi jarak jauh di perguruan tinggi swasta. Jurnal Analisis Sistem Pendidikan Tinggi, 2(1), 39-50.

Misbah, Pratama, W. A., Hartini, S., \& Dewantara, D. (2018). Pengembangan e-learning berbasis schoology pada materi impuls dan momentum untuk melatihkan literasi digital. PSEJ (Pancasakti Science Education Journal), 3(2), 109-114.

Murni, C, K., \& Harimurti, R. (2016). Pengaruh E-Learning Berbasis Schoology Terhadap Peningkatan Hasil Belajar Siswa dalam Materi Perangkat Keras Jaringan Kelas X TKJ 2 pada SMK Negeri 3 Buduran, Sidoarjo. Jurnal IT-Edu, 1(1), 86-90.

Sanova, A. (2018). Learning management system (LMS) sebagai aplikasi pengembangan materi interaktif pada mata kimia lingkungan dengan metode computer assisted instruction. Jurnal Sains Sosio Humaniora, 2(1), 61-68.

Siahaan, S. (2005). Pemanfaatan teknologi dalam penyelenggaraan pendidikan terbuka/jarak jauh. Jurnal Teknodik, 16, 19-45.

Ulva, N, L., Kantun, S., \& Widodo, J. (2017). Penerapan e-learning dengan media schoology untuk meningkatkan motivasi dan hasil belajar siswa pada kompetensi dasar mendeskripsikan konsep badan usaha dalam perekonomian Indonesia. Jurnal Pendidikan Ekonomi, 11(2), 96-102.

Zamaludin, I., Yusnaeni, W., \& Amelia S. (2016). Perancangan pembelajaran jarak jauh (E-learning) bahasa Jerman berbasis web. Jurnal PROSISKO, 3(2), 20-25.

\section{Copyright and License}

This is an open access article distributed under the terms of the Creative Commons Attribution 4.0 International License, which permits unrestricted use, distribution, and reproduction in any medium, provided the original work is properly cited.

(C) 2020 Surya Amami Pramuditya, Cita Dwi Rosita, Siska Firmasari, Sri Asnawati. 